\title{
SARS AND OTHER CORONAVIRUSES IN HUMANS AND ANIMALS
}

\author{
Leo L. M. Poon*
}

\section{INTRODUCTION}

Southeast China has long been regarded as an epicenter for influenza viruses. ${ }^{1}$ Indeed, avian influenza H5N1/97, H9N2/99, H7N7/03, and other recent avian H5 strains have occasionally crossed the species barrier in the last few years. ${ }^{2}$ These events keep reminding us that new pandemic viruses may emerge in this geographical region. However, Nature caught us by surprise when the first pandemic in this millennium was caused not by influenza viruses, or any known pathogens, but by a previously unknown virus in the subfamily of Coronaviridae.

\section{SARS CORONAVIRUS IN HUMANS}

Severe acute respiratory syndrome (SARS) is a respiratory disease newly identified in this century. The outbreak was officially recognized by the World Health Organization (WHO) in Vietnam in February 2003. ${ }^{6}$ Further investigations revealed that the outbreak was first started in Guangdong Province, China, in November 2002. ${ }^{7}$ Subsequent to its introduction to Hong Kong in mid-February 2003, the virus spread across Vietnam, Singapore, Canada, and elsewhere. In the early stage of the SARS pandemic, several pathogens were claimed to be the causative agents. Pathogens like chlamydia and paramyxoviruses were reported to be isolated from some SARS patients. ${ }^{6}$ The documentation of two human H5N1 influenza cases in February 2002 in Hong Kong also suggested the possibility of the emergence of a pandemic avian influenza virus in humans. On 17 March 2003, an international collaborative research network was set up by WHO to investigate the cause of SARS. By the end of March, colleagues from three different research groups identified a novel coronavirus $(\mathrm{CoV})$ as the etiology of SARS. ${ }^{3-5}$ Enormous efforts were taken to contain and diagnosis the disease. Unfortunately, the pandemic did not cease until July. In this outbreak, a total of 8098 probable SARS

\footnotetext{
* The University of Hong Kong, Pokfulam, Hong Kong SAR, China.
} 
patients were reported to WHO. The fatality rates in most of the affected countries ranged from $7 \%$ to $17 \%$ and 774 of probable SARS patients died from the disease.

Although previously known human CoVs account for $30 \%$ of common colds, little attention has been made on these medically important viruses. It might be mainly due to the fact that infections caused by these viruses do not result in severe illness and are usually restricted to upper respiration tract. Thus, the identification of a novel $\mathrm{CoV}$ as the pathogen for a severe viral pneumonia was far out of the expectation of most clinical virologists. With the tremendous efforts made by colleagues from the WHO collaborative network, the etiology of SARS was confirmed within weeks. ${ }^{6}$ First, viral RNA or seroconversion against SARS coronavirus was found in the majority of SARS patients. ${ }^{3-5}$ By contrast, no evidence of previous exposure of this virus could be detected from healthy individuals. ${ }^{3-5}$ Furthermore, SARS-like illness could be reproduced in experimentally infected cynomolgus macaques (Macaca fascicularis). ${ }^{8}$ Thus, this novel virus fulfills all Koch's postulates and was confirmed to be the etiological agent of SARS in mid-April 2003. ${ }^{6}$

$\mathrm{CoV}$ is an enveloped virus with a single, positive-stranded RNA genome. All CoVs have 5 major open reading frames that encode the replicase, spike (S), envelope (E), membrane $(\mathrm{M})$, and nucleocapsid $(\mathrm{N})$ proteins. These viruses can be subdivided into 3 groups. Base on antigenical and genetical studies, all previously known human coronavirus can be classified into group 1 (e.g., 229E) and group 2 (e.g., OC43). By contrast, studies on the classification of SARS-CoV yielded inconsistent results. This virus was initially shown to cross-react with group 1 coronavirus. Partial viral sequences deduced from initial studies indicated that this novel virus is genetically distinct from all previously known coronaviruses. ${ }^{3-5}$ Further characterizations of the full genome of SARS$\mathrm{CoV}$ also suggested that this virus is distantly related to groups 2 and $3 \mathrm{CoVs}{ }^{9-10}$ These findings prompted to the conclusion the SARS CoV represents a new group of CoV. However, this virus was subsequently proposed to be an early split off of the group 2 viruses. But, unlike other group 2 members, SARS-CoV does not contain a haemagglutinin-esterase protein encoding sequence. ${ }^{9-10}$ In addition, this virus also has some features that are similar to group 3 coroanviruses. ${ }^{11}$ These findings suggest that this virus might be very distinct from other group 2 viruses. ${ }^{12}$

During the SARS outbreak, several molecular and serological tests were developed for SARS diagnosis. ${ }^{13-18}$ In some of our studies, about $80 \%$ of samples from patients at early disease onset were positive in the assay. ${ }^{19,20}$ Some of these tests might have the potential to become point-of-care tests. ${ }^{21,22}$ With the experiences that we learned from these studies, we are in a better position to identify SARS patient at an early stage of disease. ${ }^{23}$ This might allow prompt clincial management and policy marking. However. further work on developing assays with better sensitivities is a must. Standardization on RT-PCR assays and clinical samples for the test might also allow us to develop a unified protocol for SARS diagnosis. In a non-pandemic situation, suspected SARS samples should be tested with caution. In an ideal situation, serial multiple samples should be collected from patients. Positive samples should be confirmed by independent assays. In addition, to avoid having false negative results, use of assays with internal positive control should be encouraged. 


\section{SARS IN ANIMALS}

The epidemiological data of early SARS patients suggested that some of these index patients might have close associations with wildlife in Guangzhou. ${ }^{24}$ This prompted us to do a virus surveillance study in a wet market in Guangzhou. In this pilot study, evidence of SARS-like CoV infection were found in those samples collected from Himalayan palm civets (Paguma larvata) and a raccoon dog (Nyctereutes procyonoides). ${ }^{25}$ In particular, SARS-like viral isolates were recovered from civets. Genetic analysis of these viral RNA indicated the human and animals isolates are of $99.8 \%$ homology. These observations indicated the SARS-CoV in human might of animal origin. Our data also suggested the human virus might be a result of direct transmission from civets to humans. Subsequent serological and epidemiological studies in humans and civets confirmed this hypothesis. Interestingly, serological and virus isolation studies both indicated that the prevalence of animal SARS-CoV in civets from farms was only about $10 \%{ }^{26}$ In particular, some of the studied farms were found to be free of this virus. By contrast, a great majority of civets in wildlife markets were found to be infected with the virus. ${ }^{26}$ These suggested that, the animals are more susceptible for SARS-CoV infection under stressful conditions. In addition, these findings also suggested that the spillover of the virus from civets to other animals and human occurred in live animal markets.

Although civets might play significant role in spreading the virus in humans, it is not known whether they are the natural reservoir for this virus. Attempts in detecting SARS$\mathrm{CoV}$ in wild civets have been made. ${ }^{27}$ In our preliminary studies, none of the samples collected from wild civets $(\mathrm{N}=21)$ were PCR positive for the virus, indicating this virus is not commonly circulating in wild civets. Nonetheless, further serological studies on wild civets and other wildlife are needed to identify the natural hosts of SARS-CoV.

\section{WILL SARS RETURN?}

The SARS outbreak was brought under control through a concerted global effort, and by July 5, 2003, no further human-human transmission took place. However, there are still several possibilities that might lead to the reemerge of SARS in human. Recent studies showed that persistent infection in human populations is unlikely, ${ }^{28}$ suggesting the chance of reemergence of SARS directly from asymptomatic infected humans is low. The potential source of SARS-CoV might come from the infected animals circulating in this geographical region. This threat was highlighted by the 4 community-acquired SARS cases between December 2003 to January 2004 in Guangdong, China. Both epidemiological and phylogenetic studies indicated the infection of these patients was from zoonotic source. ${ }^{29}$ In these recent cases, all patients only developed mild symptoms and did not cause secondary transmission, suggesting the animal virus is not fully adapted in humans yet. By contrast, the consequence of having laboratory acquired infection would be more alarming. ${ }^{30}$ Escape of these human isolates occurred three times in the past few years. These accidents were all caused by human errors, and one of these accidents caused nosocomial infections. One should note that these human viral isolates, which are stored in laboratories, could be transmitted between humans in an efficient manner. Thus, these laboratory accidents reemphasized the importance of biosafety. 


\section{NEWLY IDENTIFIED CORONAVIRUSES IN HUMAN AND ANIMALS}

After the SARS outbreak in 2003, two independent groups identified a novel CoV (HCoV-NL63) in humans. ${ }^{31,32}$ Similar to other classical human CoVs, this group 1 virus is associated with respiratory illnesses. Recent studies also indicated that this virus is a common respiratory pathogen in human populations. ${ }^{33,34}$ On the other hand, using conserved primers for CoVs, another novel human $\mathrm{CoV}$ virus (HCoV-HKU1) was recently identified. ${ }^{35}$ So far, this virus was reported to be found in a small number of patients with pneumonia in Hong Kong. Further epidemiological studies are required to demonstrate the clinical importance of this novel group 1 pathogen in global human populations.

Of all the identified $\mathrm{CoV}$ in animals, most were isolated from pets and domestic poultry. This bias is presumably because viral investigations were often imitated by observable disease outbreaks in these populations. By contrast, relative little is know about the CoVs circulating in wild animals. Recently, novel group $3 \mathrm{CoVs}$ were identified in wild birds. ${ }^{36}$ Results from this study suggested at least one of these novel viruses might cause disease in its host. ${ }^{37} \mathrm{We}$ also performed similar studies in wildlife. In this work, a novel group $1 \mathrm{CoV}$ was identified in three bat species (Miniopterus spp.) in Hong Kong. ${ }^{27}$ In particular, the prevalence of this virus in one of the bat species $(M$. pusillus) was as high as $63 \%$, suggesting this species might be the natural reservoir of this virus. Both fecal and respiratory samples from bats were positive for the virus. Our results suggested that this virus has a predominantly enteric tropism. However, it is not known whether these viruses cause disease in bat populations. In addition, we also do not know the mode of transmission of the virus. Further investigations on these topics are needed. Nonetheless, the above studies clearly highlight our poor understanding of viruses in wild animals.

\section{CONCLUSIONS}

The SARS outbreak had a severe impact on health care, the economy, and the tourist industry in many countries. Given the catastrophic consequences of SARS, further investigation on viruses in wildlife should be encouraged.

\section{ACKNOWLEDGMENTS}

The work is supported by funds from The Research Grant Council of Hong Kong, the Seed Funding and SARS Research funds from The University of Hong Kong, and European Research Project SARS-DTV (contract no. SP22-CT-2004).

\section{REFERENCES}

1. D. S. Melville and K. F. Shortridge, Influenza: time to come to grips with the avian dimension, Lancet Infect. Dis. 4, 261-262 (2004)

2. K. S. Li, Y. Guan, J. Wang, G. J. Smith, K. M. Xu, L. Duan, A. P. Rahardjo, P. Puthavathana, C. Buranathai, T. D. Nguyen, A. T. Estoepangestie, A. Chaisingh, P. Auewarakul, H. T. Long, N. T. Hanh, R. J. Webby, 
L. Poon, H. Chen, K. F. Shortridge, K. Y. Yuen, R. G. Webster, and J. S. Peiris, Genesis of a highly pathogenic and potentially pandemic H5N1 influenza virus in eastern Asia, Nature 430, 209-213 (2004).

3. J. S. Peiris, S. T. Lai, L. L. Poon, Y. Guan, L. Y. Yam, W. Lim, J. Nicholls, W. K. Yee, W. W. Yan, M. T Cheung, V. C. Cheng, K. H. Chan, D. N. Tsang, R. W. Yung, T. K. Ng, and K. Y. Yuen, Coronavirus as a possible cause of severe acute respiratory syndrome, Lancet 361, 1319-1325 (2003).

4. T. G. Ksiazek, D. Erdman, C. S. Goldsmith, S. R. Zaki, T. Peret, S. Emery, S. Tong, C. Urbani, J. A. Comer, W. Lim, P. E. Rollin, S. F. Dowell, A. E. Ling, C. D. Humphrey, W. J. Shieh, J. Guarner, C. D Paddock, P. Rota, B. Fields, J. DeRisi, J. Y. Yang, N. Cox, J. M. Hughes, J. W. LeDuc, W. J. Bellini, and L. J. Anderson, A novel coronavirus associated with severe acute respiratory syndrome, N. Engl. J. Med. 348, 1953-1966 (2003).

5. C. Drosten, S. Gunther, W. Preiser, S. van der Werf, H. R. Brodt, S. Becker, H. Rabenau, M. Panning, L. Kolesnikova, R. A. Fouchier, A. Berger, A. M. Burguiere, J. Cinatl, M. Eickmann, N. Escriou, K. Grywna, S. Kramme, J. C. Manuguerra, S. Muller, V. Rickerts, M. Sturmer, S. Vieth, H. D. Klenk, A. D. Osterhaus, H. Schmitz, and H. W. Doerr, Identification of a novel coronavirus in patients with severe acute respiratory syndrome, N. Engl. J. Med. 348, 1967-1976 (2003).

6. World Health Organization Multicentre Collaborative Network for Severe Acute Respiratory Syndrome Diagnosis, A multicentre collaboration to investigate the cause of severe acute respiratory syndrome, Lancet 361, 1730-1733 (2003).

7. N. S. Zhong, B. J. Zheng, Y. M. Li, L. L. Poon, Z. H. Xie, K. H. Chan, P. H. Li, S. Y. Tan, Q. Chang, J. P. Xie, X. Q. Liu, J. Xu, D. X. Li, K. Y. Yuen, J. S. Peiris, and Y. Guan, Epidemiology and cause of severe acute respiratory syndrome (SARS) in Guangdong, People's Republic of China, in February, 2003, Lancet 362, 1353-1358 (2003).

8. R. A. Fouchier, T. Kuiken, M. Schutten, G. van Amerongen, G. J. van Doornum, B. G. van den Hoogen, M. Peiris, W. Lim, K. Stohr, and A. D. Osterhaus, Aetiology: Koch's postulates fulfilled for SARS virus, Nature 423, 240 (2003)

9. M. A. Marra, S. J. Jones, C. R. Astell, R. A. Holt, A. Brooks-Wilson, Y. S. Butterfield, J. Khattra, J. K. Asano, S. A. Barber, S. Y. Chan, A. Cloutier, S. M. Coughlin, D. Freeman, N. Girn, O. L. Griffith, S. R. Leach, M. Mayo, H. McDonald, S. B. Montgomery, P. K. Pandoh, A. S. Petrescu, A. G. Robertson, J. E. Schein, A. Siddiqui, D. E. Smailus, J. M. Stott, G. S. Yang, F. Plummer, A. Andonov, H. Artsob, N. Bastien, K. Bernard, T. F. Booth, D. Bowness, M. Czub, M. Drebot, L. Fernando, R. Flick, M. Garbutt, M. Gray, A. Grolla, S. Jones, H. Feldmann, A. Meyers, A. Kabani, Y. Li, S. Normand, U. Stroher, G. A Tipples, S. Tyler, R. Vogrig, D. Ward, B. Watson, R. C. Brunham, M. Krajden, M. Petric, D. M. Skowronski, C. Upton, and R. L. Roper, The Genome sequence of the SARS-associated coronavirus, Science 300, 1399-1404 (2003).

10. P. A. Rota, M. S. Oberste, S. S. Monroe, W. A. Nix, R. Campagnoli, J. P. Icenogle, S. Penaranda, B. Bankamp, K. Maher, M. H. Chen, S. Tong, A. Tamin, L. Lowe, M. Frace, J. L. DeRisi, Q. Chen, D. Wang, D. D. Erdman, T. C. Peret, C. Burns, T. G. Ksiazek, P. E. Rollin, A. Sanchez, S. Liffick, B. Holloway, J. J. Limor, K. McCaustland, M. Olsen-Rasmussen, R. Fouchier, S. Gunther, A. D. Osterhaus, C. Drosten, M. A Pallansch, L. J. Anderson, and W. J. Bellini, Characterization of a novel coronavirus associated with severe acute respiratory syndrome, Science 300, 1394-1399 (2003).

11. J. Stavrinides and D. S. Guttman, Mosaic evolution of the severe acute respiratory syndrome coronavirus, J. Virol. 78, 76-82 (2004)

12. A. E. Gorbalenya, E. J. Snijder, and W. J. Spaan, Severe acute respiratory syndrome coronavirus phylogeny: toward consensus, J. Virol. 78, 7863-7866 (2004).

13. L. L. Poon, O. K. Wong, K. H. Chan, W. Luk, K. Y. Yuen, J. S. Peiris, and Y. Guan, Rapid diagnosis of a coronavirus associated with severe acute respiratory syndrome (SARS), Clin. Chem. 49, 953-955 (2003).

14. W. C. Yam, K. H. Chan, L. L. Poon, Y. Guan, K. Y. Yuen, W. H. Seto, and J. S. Peiris, Evaluation of reverse transcription-PCR assays for rapid diagnosis of severe acute respiratory syndrome associated with a novel coronavirus, J. Clin. Microbiol. 41, 4521-4524 (2003).

15. L. L. Poon, K. H. Chan, and J. S. Peiris, Crouching tiger, hidden dragon: the laboratory diagnosis of severe acute respiratory syndrome, Clin. Infect. Dis. 38, 297-299 (2004).

16. L. L. Poon, K. H. Chan, O. K. Wong, T. K. Cheung, I. Ng, B. Zheng, W. H. Seto, K. Y. Yuen, Y. Guan, and J. S. Peiris, Detection of SARS coronavirus in patients with severe acute respiratory syndrome by conventional and real-time quantitative reverse transcription-PCR assays, Clin. Chem. 50, 67-72 (2004).

17. S. K. Lau, P. C. Woo, B. H. Wong, H. W. Tsoi, G. K. Woo, R. W. Poon, K. H. Chan, W. I. Wei, J. S. Peiris, and K. Y. Yuen, Detection of severe acute respiratory syndrome (SARS) coronavirus nucleocapsid protein in sars patients by enzyme-linked immunosorbent assay, J. Clin. Microbiol. 42, 2884-2889 (2004).J

18. S. K. Lau, X. Y. Che, P. C. Woo, B. H. Wong, V. C. Cheng, G. K. Woo, I. F. Hung, R. W. Poon, K. H. Chan, J. S. Peiris, and K. Y. Yuen, SARS Coronavirus Detection Methods, Emerg. Infect. Dis. 11, 1108 1111 (2005). 
19. L. L. Poon, K. H. Chan, O. K. Wong, W. C. Yam, K. Y. Yuen, Y. Guan, Y. M. Lo, and J. S. Peiris, Early diagnosis of SARS coronavirus infection by real time RT-PCR, J. Clin. Virol. 28, 233-238 (2003).

20. L. L. Poon, B. W. Wong, K. H. Chan, C. S. Leung, K. Y. Yuen, Y. Guan, and J. S. Peiris, A one step quantitative RT-PCR for detection of SARS coronavirus with an internal control for PCR inhibitors, J. Clin. Virol. 30, 214-217 (2004).

21. L. L. Poon, C. S. Leung, M. Tashiro, K. H. Chan, B. W. Wong, K. Y. Yuen, Y. Guan, and J. S. Peiris, Rapid detection of the severe acute respiratory syndrome (SARS) coronavirus by a loop-mediated isotherma amplification assay, Clin. Chem. 50, 1050-1052 (2004).

22. L. L. Poon, B. W. Wong, K. H. Chan, S. S. Ng, K. Y. Yuen, Y. Guan, and J. S. Peiris, Evaluation of realtime reverse transcriptase PCR and real-time loop-mediated amplification assays for severe acute respiratory syndrome coronavirus detection, J. Clin. Microbiol. 43, 3457-3459 (2005).

23. L. L. Poon, Y. Guan, J. M. Nicholls, K. Y. Yuen, and J. S. Peiris, The aetiology, origins, and diagnosis of severe acute respiratory syndrome, Lancet Infect. Dis. 4, 663-671 (2004).

24. R. H. Xu, J. F. He, M. R. Evans, G. W. Peng, H. E. Field, D. W. Yu, C. K. Lee, H. M. Luo, W. S. Lin, P. Lin, L. H. Li, W. J. Liang, J. Y. Lin, and A. Schnur, Epidemiologic clues to SARS origin in China, Emerg. Infect. Dis. 10, 1030-1037 (2004).

25. Y. Guan, B. J. Zheng, Y. Q. He, X. L. Liu, Z. X. Zhuang, C. L. Cheung, S. W. Luo, P. H. Li, L. J. Zhang, Y. J. Guan, K. M. Butt, K. L. Wong, K. W. Chan, W. Lim, K. F. Shortridge, K. Y. Yuen, J. S. Peiris, and L. L. Poon, Isolation and characterization of viruses related to the SARS coronavirus from animals in southern China, Science 302, 276-278 (2003).

26. C. Tu, G. Crameri, X. Kong, J. Chen, Y. Sun, M. Yu, H. Xiang, X. Xia, S. Liu, T. Ren, Y. Yu, B. T. Eaton, H. Xuan, and L. F. Wang, Antibodies to SARS coronavirus in civets, Emerg. Infect. Dis. 10, 2244-2248 (2004).

27. L. L. Poon, D. K. Chu, K. H. Chan, O. K. Wong, T. M. Ellis, Y. H. Leung, S. K. Lau, P. C. Woo, K. Y. Suen, K. Y. Yuen, Y. Guan, and J. S. Peiris, Identification of a novel coronavirus in bats, J. Virol. 79, 2001 2009 (2005).

28. G. M. Leung, L. M. Ho, S. K. Chan, S. Y. Ho, J. Bacon-Shone, R. Y. Choy, A. J. Hedley, T. H. Lam, and R. Fielding, Longitudinal assessment of community psychobehavioral responses during and after the 2003 outbreak of severe acute respiratory syndrome in Hong Kong, Clin. Infect. Dis. 40, 1713-1720 (2005).

29. H. D. Song, C. C. Tu, G. W. Zhang, S. Y. Wang, K. Zheng, L. C. Lei, Q. X. Chen, Y. W. Gao, H. Q. Zhou, H. Xiang, H. J. Zheng, S. W. Chern, F. Cheng, C. M. Pan, H. Xuan, S. J. Chen, H. M. Luo, D. H. Zhou, Y. F. Liu, J. F. He, P. Z. Qin, L. H. Li, Y. Q. Ren, W. J. Liang, Y. D. Yu, L. Anderson, M. Wang, R. H. Xu, X W. Wu, H. Y. Zheng, J. D. Chen, G. Liang, Y. Gao, M. Liao, L. Fang, L. Y. Jiang, H. Li, F. Chen, B. Di, L. J. He, J. Y. Lin, S. Tong, X. Kong, L. Du, P. Hao, H. Tang, A. Bernini, X. J. Yu, O. Spiga, Z. M. Guo, H. Y. Pan, W. Z. He, J. C. Manuguerra, A. Fontanet, A. Danchin, N. Niccolai, Y. X. Li, C. I. Wu, and G. P. Zhao, Cross-host evolution of severe acute respiratory syndrome coronavirus in palm civet and human, Proc. Natl. Acad. Sci. USA 102, 2430-2435 (2005).

30. C. Orellana, Laboratory-acquired SARS raises worries on biosafety, Lancet Infect. Dis. 4, 64 (2004).

31. L. van der Hoek, K. Pyrc, M. F. Jebbink, W. Vermeulen-Oost, R. J. Berkhout, K. C. Wolthers, P. M. Wertheim-van Dillen, J. Kaandorp, J. Spaargaren, and B. Berkhout, Identification of a new human coronavirus, Nat. Med. 10, 368-373 (2004).

32. R. A. Fouchier, N. G. Hartwig, T. M. Bestebroer, B. Niemeyer, J. C. de Jong, J. H. Simon, and A. D. Osterhaus, A previously undescribed coronavirus associated with respiratory disease in humans, Proc. Natl. Acad. Sci. USA 101, 6212-6216 (2004).

33. S. S. Chiu, K. H. Chan, K. W. Chu, S. W. Kwan, Y. Guan, L. L. Poon, and J. S. Peiris, Human coronavirus NL63 infection and other coronavirus infections in children hospitalized with acute respiratory disease in Hong Kong, China, Clin. Infect. Dis. 40, 1721-1729 (2005).

34. N. Bastien, K. Anderson, L. Hart, P. Van Caeseele, K. Brandt, D. Milley, T. Hatchette, E. C. Weiss, and Y. Li, Human coronavirus NL63 infection in Canada, J. Infect. Dis. 191, 503-506 (2005).

35. P. C. Woo, S. K. Lau, C. M. Chu, K. H. Chan, H. W. Tsoi, Y. Huang, B. H. Wong, R. W. Poon, J. J. Cai, W. K. Luk, L. L. Poon, S. S. Wong, Y. Guan, J. S. Peiris, and K. Y. Yuen, Characterization and complete genome sequence of a novel coronavirus, coronavirus HKU1, from patients with pneumonia, J. Virol. 79, 884-895 (2005)

36. C. M. Jonassen, T. Kofstad, I. L. Larsen, A. Lovland, K. Handeland, A. Follestad, and A. Lillehaug, Molecular identification and characterization of novel coronaviruses infecting graylag geese (Anser anser), feral pigeons (Columbia livia) and mallards (Anas platyrhynchos), J. Gen. Virol. 86, 1597-1607 (2005). 